\title{
Notification of cases of HIV/AIDS among the elderly in the state of Ceará: the historical sequence between 2005 and 2014
}

\author{
David de Alencar Correia Maia ${ }^{1}$ \\ Luciane Zanin? \\ Almenara de Souza Fonseca Silva? \\ Gláucia Maria Bovi Ambrosano² \\ Flávia Martão Flório'
}

Abstract

Objective: to describe the historical sequence and characteristics of reported cases of HIV/ AIDS among the elderly in the state of Ceará from 2005 to 2014. Method: a descriptive study was carried out, based on the Ministry of Health database, available in SINAN (Disease Cases Notification Information System) from January 2005 to December 2014. The variables studied were: gender, race, schooling, marital status and exposure category. Result: a total of 10,299 new cases were reported in the state, 1.5\% (151) of which related to the elderly. The majority of those affected lived in Fortaleza $(85.6 \%)$, were aged between 60 and 69 years $(86.8 \%)$, were male $(60.9 \%)$, brown $(61.6 \%)$, had a level of schooling below unfinished elementary (42\%), were heterosexual $(85.4 \%)$ and had a marital status of married (29.3\%). The proportion of male/female cases peaked in 2005 (5.5: 1) and declined thereafter reaching an average value of $0.8: 1$ in the period between 2008 and 2011, then increased again, reaching 3.3: 1 in 2014. The highest coefficients were observed in the groups with lower schooling. Conclusion: according to the notifications during the period evaluated, AIDS among the elderly showed a tendency of growth among men, aged between 60 and 69 years old, who were heterosexual, less educated and married. This justifies the strengthening of specific strategies aimed at this population with the objective of tackling the disease.

\footnotetext{
Faculdade São Leopoldo Mandic, Curso de Odontologia. Departamento de Saúde Coletiva. Campinas, São Paulo, Brasil.

2 Universidade Estadual de Campinas, Faculdade de Odontologia de Piracicaba. Departamento de Odontologia Social. Piracicaba, São Paulo, Brasil.
}

\section{Keywords: Disease} Notification. Health of the Elderly. Acquired Immunodeficency Syndrome. Sexuality. 


\section{INTRODUCTION}

The exercise of sexuality is one of the facets used to evaluate the "social relations" domain of the instrument used by the World Health Organization (WHO) for the evaluation of quality of life $e^{1}$. In the context of aging it is a factor of significant importance for the quality of life of the elderly $y^{2-5}$.

Aging does not diminish interest in sex, which can be experienced in different ways ${ }^{4,5}$, and it is possible to continue the exercise of sexuality throughout human life, especially in old age ${ }^{6}$. Despite this, the theme of sexuality is not always treated openly, especially in relation to old age, as it refers to intimate experiences, and it is even treated with prejudice in some cases $^{5,7}$.

The technology involved in the development of new drugs has reduced the discomfort caused by advancing age in the area of sex, allowing the consequences and limitations resulting from the natural process of human aging to be reversed ${ }^{8}$. Studies in this area ${ }^{9,10}$ have identified an increase in the number of cases of sexually transmitted infections in this age group.

Among the factors cited to explain the increase in the number of HIV/AIDS cases among the elderly population are the increase in the use of medications to control sexual impotence, prejudice in relation to sexuality in old age ${ }^{11}$, the shortage of health strategies that inform the elderly about the prevention of sexually transmitted infections and the lack of knowledge of pathology of this population segment ${ }^{12,13}$.

In response to the increased incidence of HIV among the elderly, in 2008 and 2009 the National STD and AIDS Program carried out campaigns that sought to emphasize the importance of using condoms in sexual relations. The WHO recognizes Brazil as one of the pioneers in initiating such campaigns due to the increased incidence of the disease ${ }^{13}$. More recently, the Department of Surveillance, Prevention and Control of Sexually Transmissible Infections (STI), HIV/AIDS and viral hepatitis of the Ministry of Health has centralized decision-making and strategy planning in this area.
However, while the interventions of the Brazilian government in relation to HIV/AIDS and strategies focusing on information about and prevention of the disease aimed at the elderly still occur, they are not continuous $^{2}$. This is most likely because of the social conception that "old age is asexual," which means health professionals who care for the elderly generally fail to consider the possibility of HIV infection, and as a consequence, do not provide information about sexually transmitted infections, communicable diseases and AIDS. Despite this restricted view, both in terms of sexuality and old age, unprotected sexual exposure is today the main form of HIV infection among the elderly ${ }^{10}$.

When the sexuality of the elderly is denied socially, they end up at a disadvantage in relation to preventive campaigns on HIV/AIDS. As a result, the information provided is insufficient to ensure the prevention of the disease, contributing to increasing vulnerability ${ }^{14}$.

The first case of AIDS among the elderly in the northeast of Brazil occurred in the state of Ceará in 1983, although the patient came from the southeast of the country ${ }^{14}$. In 20045,763 new cases were registered in the state, of which 116 affected the elderly ${ }^{15}$. In 2012, around 800 AIDS cases were reported, of which $53.7 \%$ were related to people living in the state capital. With regard to the internal distribution of HIV/AIDS, $96 \%$ of all municipal regions in Ceará have identified at least one case of AIDS ${ }^{16}$.

The present study aims to describe the time series and characteristics of the reported cases of HIV/AIDS among the elderly in the state of Ceará between 2005 and 2014.

\section{METHOD}

This descriptive epidemiological study was carried out based on an analysis of secondary data from the Disease Cases Notification Information System (SINAN) of the state of Ceará, made available by the Department of Informatics of the Unified Health System (DATASUS), from January 2005 to December 2014. For data collection, the reported cases of HIV/AIDS involving individuals aged 60 considered the following variables: 
a) Individual characteristics of subject:

- Gender: male or female;

- Race: white, black, brown, yellow or not informed;

- Age: categorized into: 60 to 69 years, 70 to 79 years and over 80 years.

b) Social characteristics of subjects

- Schooling: illiterate, 1 st to 4 th grade incomplete, 1 st to 4 th grade complete, 5 th to 8 th grade incomplete, complete elementary education, incomplete secondary education, complete secondary education, incomplete higher education, complete higher education, not informed.

- Marital status: single, married, legally separated, widowed, other, not informed.

- Category of exposure: heterossexual, homossexual and bissexual.
A descriptive analysis of the data was performed and the Fisher's Exact test was used to verify the association between the analyzed variables and age group, considering a level of significance of $5 \%$. The analyzes were performed in the SAS program (Institute Inc., Cary, NC, USA, Release 9.2, 2010).

\section{RESULTS}

During the study period, 151 (1.47\%) of the 10,299 new HIV/AIDS cases reported in the state involved individuals aged 60 years or older. Table 1 shows the variation in the number of cases reported in relation to the year analyzed. The number of cases per 100,000 inhabitants more than doubled in the period evaluated for the overall population and oscillated among the elderly, varying from 0.13 cases $/ 100,000$ inhabitants in 2011 to 0.28 cases/100,000 inhabitants in 2012 .

Figure 1 shows the HIV/AIDS trend lines, considering the overall and the elderly population in the state of Ceará, during the evaluation period. An increasing trend in cases was noted in the period among both the overall and the elderly population.

Table 1. Distribution of frequencies of reported cases of HIV/AIDS in Ceará, from 2005 to 2014, in relation to the overall population.

\begin{tabular}{llllll}
\hline \multirow{2}{*}{ Year of Notification } & Population of State & \multicolumn{2}{l}{ Population with HIV ${ }^{1}$} & \multicolumn{2}{l}{ Elderly persons with HIV ${ }^{2}$} \\
\cline { 3 - 6 } & & $\mathrm{N}$ & Cases/100,000 inhab.. & $\mathrm{n}(\%)$ & Cases/100,000 inhab. \\
\hline 2005 & $8,097,276$ & 463 & 5.72 & $13(2.81)$ & 0.16 \\
2006 & $8,217,140$ & 724 & 8.81 & $14(1.93)$ & 0.17 \\
2007 & $8,335,849$ & 816 & 9.79 & $13(1.59)$ & 0.16 \\
2008 & $8,450,527$ & 753 & 8.91 & $19(2.52)$ & 0.22 \\
2009 & $8,547,750$ & 1233 & 14.42 & $13(1.05)$ & 0.15 \\
2010 & $8,452,381$ & 1548 & 18.31 & $13(0.84)$ & 0.15 \\
2011 & $8,530,155$ & 1414 & 16.58 & $11(0.78)$ & 0.13 \\
2012 & $8,606,005$ & 1228 & 14.27 & $24(1.95)$ & 0.28 \\
2013 & $8,840,000$ & 1071 & 12.12 & $18(1.68)$ & 0.20 \\
2014 & $8,904,459$ & 1049 & 11.78 & $13(1.24)$ & 0.15 \\
\hline Period & $8,498,154$ & 10299 & 121.19 & $151(1.47)$ & 1.78 \\
\hline
\end{tabular}

${ }^{1}$ Frequency in relation to overall population; ${ }^{2}$ Frequency in relation to people with HIV; ${ }^{3}$ Inhabitants. 

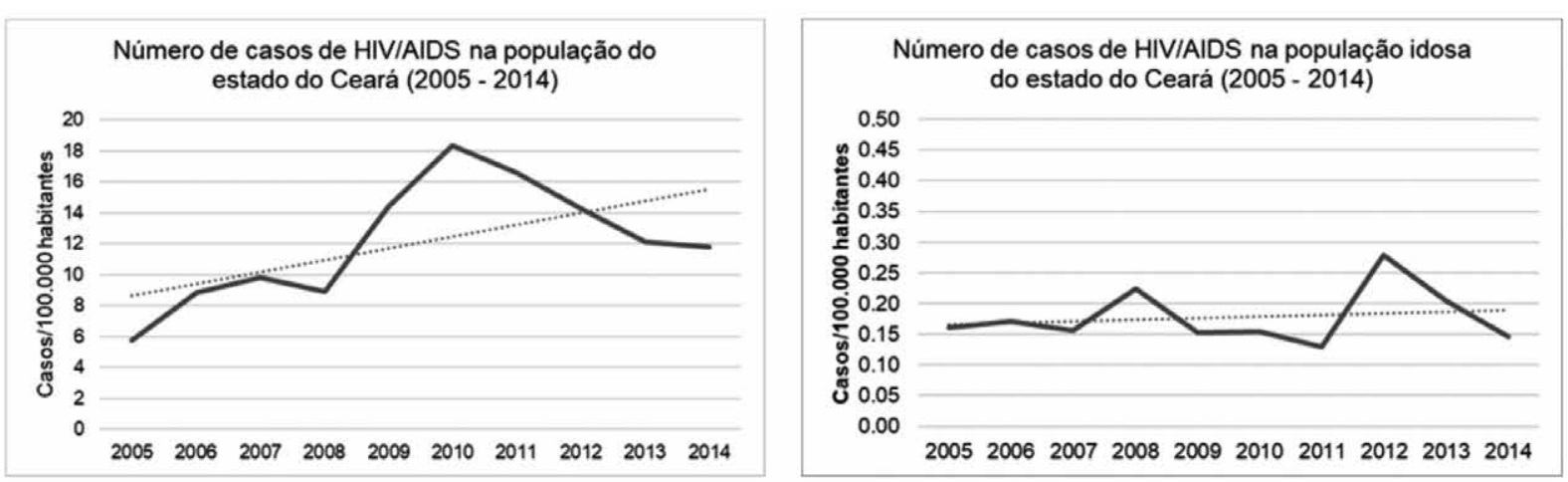

Figure 1. Trends in notifications of cases of HIV/AIDS in the overall population and among elderly people in the state. Ceará, Brazil, 2005 - 2014.

Table 2 shows the frequency distribution of the reported cases according to sociodemographic variables. The number of reports was higher among individuals aged between 60 and 69 years $(86.8 \%)$, men $(60.9 \%)$, those with brown skin colour/race $(61.6 \%)$ a predominantly lower educational level $(42 \%)$ and heterosexual (85\%).

Considering the age classes tested, no association was found between the frequency of HIV/AIDS cases, gender, race and level of education ( $p>0.05)$. Regarding marital status and type of exposure, it was noted that among those aged 60 to 69 years, there was a predominance of elderly people who declared themselves to be married and heterosexual, while for the other age groups, those declaring themselves to be unmarried, homosexual and bisexual predominated. For the marital status and schooling variables, most of the notifications provided incomplete information, which were considered as not informed. 
Table 2. Distribution of frequencies of notified cases of HIV/AIDS among the elderly in Ceará, by age range, from 2005 to 2014, in function of sociodemographic variables.

\begin{tabular}{|c|c|c|c|c|c|}
\hline \multirow[t]{3}{*}{ Variable } & \multicolumn{3}{|l|}{ Age range } & \multirow[t]{2}{*}{ Total } & \multirow[t]{2}{*}{$p$-value* } \\
\hline & 60 to 69 years & 70 to 79 years & $>79$ years & & \\
\hline & $\mathrm{n}(\$ 0 \%)$ & $\mathrm{n}(\$ 0 \%)$ & $\mathrm{n}(\$ 0 \%)$ & $\mathrm{n}(\# 0)$ & \\
\hline \multicolumn{6}{|l|}{ Gender } \\
\hline Male & $78(84.8)$ & $11(12.0)$ & $3(3.3)$ & $92(60.9)$ & 0.5829 \\
\hline Female & $53(89.8)$ & $4(6.8)$ & $2(3.4)$ & $59(39.1)$ & \\
\hline $\mathrm{M} / \mathrm{F}$ ratio & $1.5: 1$ & $2.7: 1$ & $1.5: 1$ & 1.6:1 & \\
\hline \multicolumn{6}{|l|}{ Race } \\
\hline White & $13(81.2)$ & $2(12.5)$ & $1(6.3)$ & $16(10.6)$ & 0.5277 \\
\hline Non-white & $117(87.5)$ & $13(9.7)$ & $4(3.0)$ & $134(88.7)$ & \\
\hline Not informed & $1(100.0)$ & $0(0.0)$ & $0(0.0)$ & $1(0.7)$ & \\
\hline \multicolumn{6}{|l|}{ Marital status } \\
\hline Married & $29(93.5)$ & $1(3.2)$ & $1(3.2)$ & $31(20.5)$ & 0.0285 \\
\hline Not married & $32(71.1)$ & $10(22.2)$ & $3(6.7)$ & $45(29.8)$ & \\
\hline Not informed & $70(93.3)$ & $4(5.3)$ & $1(1.3)$ & $75(49.7)$ & \\
\hline \multicolumn{6}{|l|}{ Degree of exposure } \\
\hline Homosexual/Bisexual & $14(63.6)$ & $5(22.7)$ & $3(13.6)$ & $22(14.6)$ & 0.0025 \\
\hline Heterosexual & $117(90.7)$ & $10(7.8)$ & $2(1.6)$ & $129(85.4)$ & \\
\hline Not informed & $0(0.0)$ & $0(0.0)$ & $0(0.0)$ & $0(0.0)$ & \\
\hline \multicolumn{6}{|l|}{ Schooling } \\
\hline Illiterate & $15(88.2)$ & $1(5.9)$ & $1(5.9)$ & $17(11.2)$ & 0.7644 \\
\hline Up to complete elementary & $42(85.7)$ & $6(12.2)$ & $1(2.0)$ & $49(32.4)$ & \\
\hline Over complete elementary & $15(93.8)$ & $1(6.2)$ & $0(0.0)$ & $16(10.6)$ & \\
\hline Uninformed & $59(85.5)$ & $7(10.1)$ & $3(4.3)$ & $69(45.7)$ & \\
\hline Total & $131(86.8)$ & $15(9.9)$ & $5(3.3)$ & $151(100.0)$ & \\
\hline
\end{tabular}

\$ Percentage on line within each variable; ${ }^{*}$ Percentage in column within each variable. For statistical analysis the uninformed cases were withdrawn; * Fisher's Exact Test.

Table 3 shows the variables analyzed based on year of notification and gender, race, education level and marital status. In general, there was a greater number of cases among men, with the exception of the years 2008, 2010 and 2011. There was a downward trend in the male/female ratio of new cases of HIV/ AIDS until 2011, but this increased again afterwards, climbing as high as 3.3 diagnosed men for every one diagnosed woman (3.3:1).
Table 4 shows that, in relation to category of exposure, the majority $(76.1 \%)$ of the men notified were in the heterosexual category, followed by the homosexual category (15.2\%). Among women, all cases occurred by heterosexual transmission. There was no significant association $(p<0.001)$ between Category of Exposure and gender. 


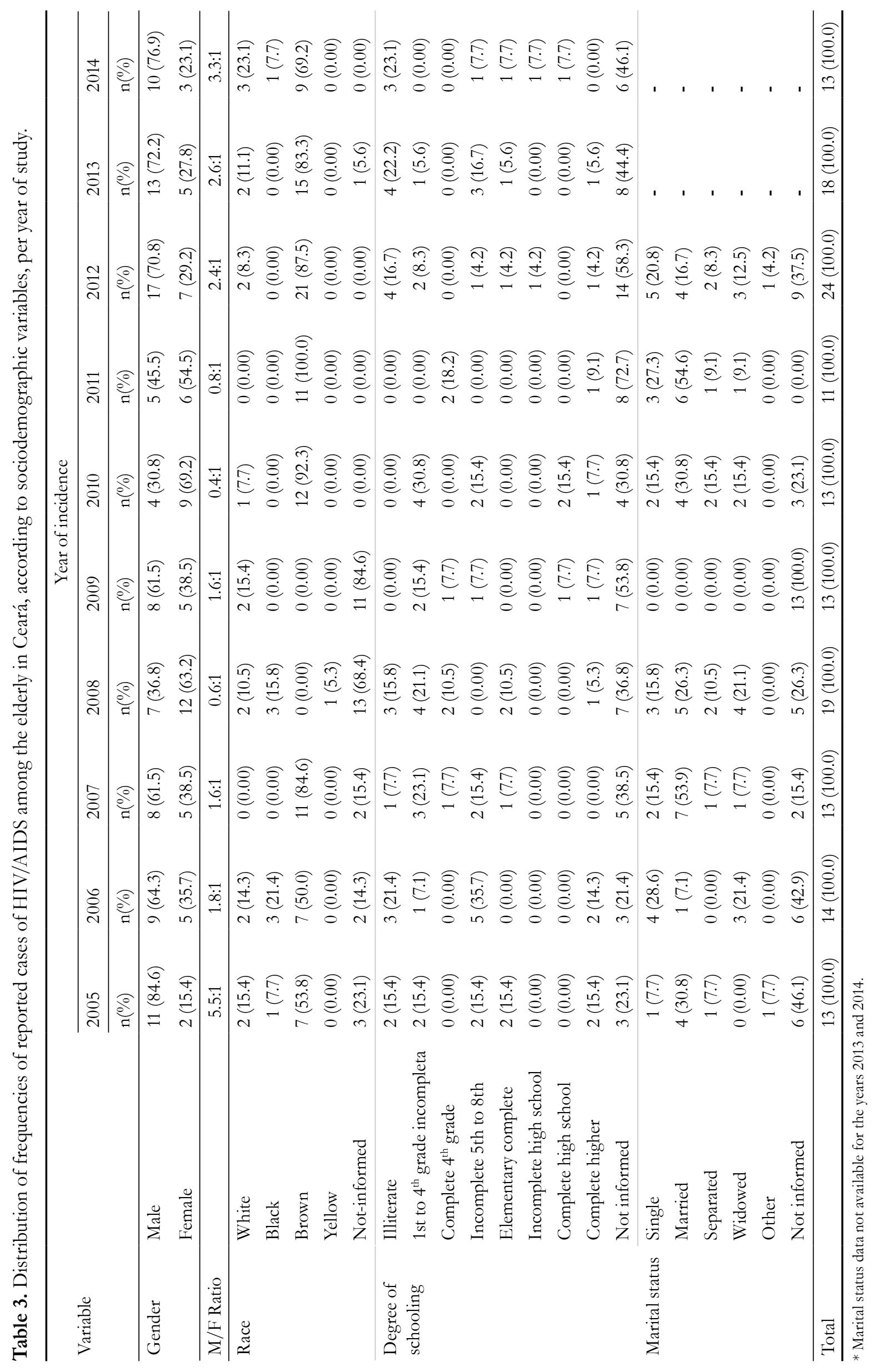


Table 4. Distribution of the number of HIV/AIDS cases among the elderly, according to the Category of Exposure, year of notification and gender.

\begin{tabular}{|c|c|c|c|c|}
\hline \multirow[t]{2}{*}{ Year } & \multirow[t]{2}{*}{ Category } & Male & Female & Total \\
\hline & & $\mathrm{N}(\# \%)$ & $\mathrm{N}(\# \%)$ & $\mathrm{N}(\# \%)$ \\
\hline \multirow[t]{2}{*}{2005} & Heterosexual & $11(100.0)$ & $2(100.0)$ & $13(100.0)$ \\
\hline & Total partial & $11(100.0)$ & $2(100.0)$ & $13(100.0)$ \\
\hline \multirow[t]{4}{*}{2006} & Homosexual & $1(11.1)$ & $0(0.0)$ & $1(7.1)$ \\
\hline & Bisexual & $1(11.1)$ & $0(0.0)$ & $1(7.1)$ \\
\hline & Heterosexual & $7(77.8)$ & $5(100.0)$ & $12(85.2)$ \\
\hline & Total partial & $9(100.0)$ & $5(100.0)$ & $14(100.0)$ \\
\hline \multirow[t]{4}{*}{2007} & Homosexual & $3(37.5)$ & $0(0.0)$ & $3(23.1)$ \\
\hline & Bisexual & $1(12.5)$ & $0(0.0)$ & $1(7.7)$ \\
\hline & Heterosexual & $4(50.0)$ & $5(100.0)$ & $9(69.2)$ \\
\hline & Total partial & $8(100.0)$ & $5(100.0)$ & $13(100.0)$ \\
\hline \multirow[t]{4}{*}{2008} & Homosexual & $1(14.3)$ & $0(0.0)$ & $1(5.3)$ \\
\hline & Bisexual & $1(14.3)$ & $0(0.0)$ & $1(5.3)$ \\
\hline & Heterosexual & $5(71.4)$ & $12(100.0)$ & $17(89.5)$ \\
\hline & Total partial & $7(100.0)$ & $12(100.0)$ & $19(100.0)$ \\
\hline \multirow[t]{4}{*}{2009} & Homosexual & $1(12.5)$ & $0(0.0)$ & $1(7.7)$ \\
\hline & Bisexual & $1(12.5)$ & $0(0.0)$ & $1(7.7)$ \\
\hline & Heterosexual & $6(75.0)$ & $5(100.0)$ & $11(84.6)$ \\
\hline & Total partial & $8(100.0)$ & $5(100.0)$ & $13(100.0)$ \\
\hline \multirow[t]{4}{*}{2010} & Homosexual & $1(25.0)$ & $0(0.0)$ & $1(7.7)$ \\
\hline & Bisexual & $1(25.0)$ & $0(0.0)$ & $1(7.7)$ \\
\hline & Heterosexual & $2(50.0)$ & $9(100.0)$ & $11(84.6)$ \\
\hline & Total partial & $4(100.0)$ & $9(100.0)$ & $13(100.0)$ \\
\hline \multirow[t]{2}{*}{2011} & Heterosexual & $5(100.0)$ & $6(100.0)$ & $11(100.0)$ \\
\hline & Total partial & $5(100.0)$ & $6(100.0)$ & $11(100.0)$ \\
\hline \multirow[t]{4}{*}{2012} & Homosexual & $3(17.7)$ & $0(0.0)$ & $3(12.5)$ \\
\hline & Bisexual & $1(5.9)$ & $0(0.0)$ & $1(4.2)$ \\
\hline & Heterosexual & $13(76.5)$ & $7(100.0)$ & $20(83.3)$ \\
\hline & Total partial & $17(100.0)$ & $7(100.0)$ & $24(100.0)$ \\
\hline \multirow[t]{4}{*}{2013} & Homosexual & $4(30.8)$ & $0(0.0)$ & $4(22.2)$ \\
\hline & Bisexual & $1(7.7)$ & $0(0.0)$ & $1(5.6)$ \\
\hline & Heterosexual & 8 (61.6) & $5(100.0)$ & $13(72.2)$ \\
\hline & Total partial & $13(100.0)$ & $5(100.0)$ & $18(100.0)$ \\
\hline \multirow[t]{3}{*}{2014} & Bisexual & $1(10.0)$ & $0(0.0)$ & $1(7.7)$ \\
\hline & Heterosexual & $9(90.0)$ & $3(100.0)$ & $12(92.3)$ \\
\hline & Total partial & $10(100.0)$ & $3(100.0)$ & $13(100.0)$ \\
\hline \multirow[t]{4}{*}{2005 a $2014 * *$} & Homosexual & 14 (15.2) & $0(0.0)$ & $14(9.3)$ \\
\hline & Bisexual & $8(8.7)$ & $0(0.0)$ & $8(5.3)$ \\
\hline & Heterosexual & $70(76.1)$ & $59(100.0)$ & $129(85.4)$ \\
\hline & Overall total & $92(100.0)$ & $59(100.0)$ & $151(100.0)$ \\
\hline
\end{tabular}

\# Percentage in column within each year. 


\section{DISCUSSION}

Data from the present study showed that the number of reports of HIV/AIDS in the state of Ceará demonstrated an increasing trend between 2005 and 2014, both among the overall population and among the elderly. This trend was also observed in Brazil between 2006 and 2015, where there was an increase in the number of cases, especially in the northeast and north ${ }^{17}$. Although the HIV/AIDS epidemic has existed in the state of Ceará for more than 30 years, almost $50 \%$ of cases were reported between 2007 and $2014^{18}$.

A greater number of cases was reported in the state among males aged between 60 and 69 years, characterizing them as the predominant segment and probably the "diffusing hub" of the epidemic ${ }^{11,19}$. It should be noted that although there was a reduction in the proportion of men in notified cases in the years 2006 to 2011, this figure increased again from 2012 to 2014.

The behavior of the ratio between the genders in this period, influenced by such fluctuations, is related to the fact that heterosexual was the most frequent category of transmission, a fact also observed in previous studies ${ }^{3,6}$.

There was an increasing trend in the proportion of notifications involving individuals with lower levels of schooling, as a lack of education increases the possibility of HIV/AIDS infection, with lower levels of schooling resulting in less effective prevention of the disease ${ }^{9,20}$. This finding may be closely related to greater access to information among individuals with higher levels of education ${ }^{21}$. Furthermore, lower levels of education are related to less knowledge about the forms of HIV/AIDS transmission ${ }^{22,23}$ which may be closely related to greater access to information among more educated individuals ${ }^{21,24}$. Lower levels of education, meanwhile, result in less knowledge about the forms of HIV/AIDS transmission ${ }^{23}$. In the northeast, illiteracy among the elderly is alarming, exceeding $40 \%$ in Ceará ${ }^{25}$. This demonstrates the importance of prevention strategies and educational campaigns, which should be clear and adapted to the level of understanding of individuals with less formal education. In contrast, it should be remembered that low educational levels can contribute to a poor understanding of the disease, even if the individual receives the correct information from reliable sources ${ }^{26}$.

In terms of age group, it can be inferred that part of the studied population must have become infected before the age of 60 , as it can take 5 to 10 years for notification to become effective ${ }^{27}$.

Regarding gender, several authors, in agreement with the findings of the present study, have found that men are the most affected, regardless of age ${ }^{11,13,20,21,28}$, although a process of feminization is occurring ${ }^{15,27,29}$. In the study period, it was observed that in three years $(2008,2010$ and 2011) the number of notifications was higher among women.

Since Law no 9.313/96 was passed in 1996, individuals with HIV/AIDS have benefited from free and universal access to antiretrovirals, which has increased the chance of survival, even among age groups not previously covered by such care ${ }^{15}$. In addition, the notification of cases, the provision of prophylactic measures to prevent the vertical transmission of the virus ${ }^{30}$, the diagnostic support of Test and Counselling Centers (CTA) and a surveillance policy with studies of specific population groups involving strategies aimed at reducing harm to health through the misuse of injecting drugs and free supply of condoms have all become compulsory ${ }^{26}$.

There is a need for more campaigns aimed at the elderly in order to raise awareness of the need to use condoms, as while the evolution of pharmacology and medicine has provided this group with a longer active sexual life, cultural factors have increased the risk of acquiring HIV/AIDS and other diseases ${ }^{14}$. The use of condoms among the elderly is low, either due to a lack of understanding about their importance in the postmenopausal period, or due to the difficulty of negotiation between partners with regard to adopting safer sexual practices, in addition to reduced knowledge about the transmission routes of HIV, low perception of the risk of HIV infection motivated by the woman's trust in a stable relationship, and the possibility that requesting to use condoms can generate suspicions of infidelity. This phenomenon was identified in the present research, given the large number of married elderly persons among the cases reported, which is in accordance with data from literature $^{4,6,15,21,24,27 \text {. }}$ 
In Brazil, great progress has already been made in relation to health and social care, especially with regard to the legalization of the rights of the elderly? However, health actions aimed at older people tend to focus on HIV/AIDS, and are diluted amongst care for other age groups. For these campaigns to be more widespread, it is necessary to involve various institutional sectors and civil society, such as social centers and churches, in conjunction with health and social care professionals, in order to reduce the stigma surrounding the sexual needs of the elderly, so that they can discuss topics related to their sexuality more easily.

It is understood that more studies on this little explored topic are required, as they can contribute to more effective interventions, through the dissemination of information to the elderly, health professionals and family members.

The present study is limited in the depth of its investigation of the question of sexuality and drug use, due to the lack of this information in the researched database, and in the large number of overlooked variables, indicating the fragility of the data produced in the information system, directly reflecting the quality of the information produced. It does, however, demonstrate the importance of a deeper discussion on the vulnerability of the elderly to HIV/AIDS, looking beyond the priority groups of adults, children and adolescents.

\section{REFERENCES}

1. Fleck MPA. O Instrumento de avaliação de qualidade de vida da Organização Mundial da Saúde (WHOQOL-100): características e perspectivas. Ciênc Saúde Colet [Internet]. 2000 [acesso em 27 jun. 2018];5(1):33-8. Disponível em: http://www. scielo.br/scielo.php?script $=$ sci_arttext\&pid=S1413$81232000000100004 \& \operatorname{lng}=$ pt\&tlng=pt

2. Oliveira FBM, Queiroz AAFLN, Sousa AFL, Moura MEB, Reis RK. Sexual orientation and quality of life of people living with HIV/Aids. Rev Bras Enferm. 2017;70(5):1004-10. Thematic Edition "Good Practices: Fundamentals of Nursing work in the construction of a democratic society.
To achieve a holistic approach to HIV/AIDS in this population, there is a need to understand the biological and cultural processes involved in sexuality and autonomous and healthy aging, which go beyond the idea of a dependent elderly person who is sick and awaiting death. Sexuality among the elderly has to be treated and stimulated within a healthy practice and without stigmas, so that it becomes another factor that contributes to an autonomous and full life for this population.

\section{CONCLUSION}

The reports of cases of HIV/AIDS among the elderly demonstrated a slightly increasing trend in the period evaluated. It was found that the number of notifications was greater among men, aged 60 to 69 years, who were heterosexual, had low levels of schooling and were married. The identification of this profile and trend can contribute to the planning of health actions related to HIV/AIDS, with the emphasis on the use of condoms by elderly people, while a multisectoral effort is needed to reduce the stigma that involves the sexual needs of this age group. The need for further studies in this area is also emphasized, as these can contribute to more effective interventions by disseminating information among the elderly, health professionals and family members, thus improving geriatric and gerontological practice.

3. Lowsky DJ, Olshansky SJ, Bhattacharya J, Goldman DP. Heterogeneity in healthy aging. J Gerontol Ser A Biol Sci Med Sci. 2014;69(6):640-9.

4. Souza JL. Sexualidade na terceira idade: uma discussão da AIDS, envelhecimento e medicamentos para disfunção erétil. DST J Bras Doenças Sex Transm. 2008;20(1):59-64.

5. Prado DJ, Neves JEF, Silva GSS, Silva ICR. O conhecimento de HIV/AIDS em idosos de uma comunidade carente do Distrito Federal. Acta Ciênc Saúde. 2017;12(1):40-9.

6. Dantas Neto FA, Santana MAS, de Lucena ECL, da Silva Soares MC, Lima KMM. Sexualidade na terceira idade: compreensão e percepção do idoso, família e sociedade. Rev Univ Vale do Rio Verde. 2014;12(1):317-26. 
7. Mendes MRSS, Barbosa, GJL, Faro ACM, Leite RCBO. A situação social do idoso no Brasil: uma breve consideração. Acta Paul Enferm [Internet]. 2005 [acesso em 14 de mar. 2017];18(4):422-6. Disponível em: http://www. scielo.br/scielo.php?script=sci_arttext\&pid=S010321002005000400011\&lng=pt\&tlng=pt

8. Campos ACV, Ferreira EF, Vargas AMD. Determinantes do envelhecimento ativo segundo a qualidade de vida e gênero. Ciênc Saúde Colet [Internet]. 2015 [acesso em 13 fev. 2015];20(7):2221-37. Disponível em: http://www. scielo.br/scielo.php?script=sci_arttext\&pid=S1413$81232015000702221 \& \operatorname{lng}=p t \& t \operatorname{lng}=p t$

9. da Silva LVS, Minervino SS, Bueno AAB, Fassarella CS. O uso do preservativo e a prevenção de doença sexualmente transmissível na terceira idade. Rev Rede Cuid Saúde. 2014;8(1):1-11.

10. Portal do Governo do Brasil [Internet]. Brasília, DF: Governo Federal; 2013 -. Sexualidade; 29 jul. 2014 [acesso em 10 jul. 2017]; [1 tela]. Disponível em: http://www.brasil.gov.br/saude/2012/04/sexualidade

11. Oliveira MLC, Paz LC, Melo GF. Dez anos de epidemia do HIV-AIDS em maiores de 60 anos no Distrito Federal - Brasil. Rev Bras Epidemiol. 2013;16(1):30-9. Disponível em: http://www.scielo.br/ scielo.php?script $=$ sci_arttext\&pid=\$1415-790X20130 00100030\&lng $=$ pt\&tlng $=$ pt

12. Neto JD, Nakamura AS, Ranieri LE, Cortez MUY. Doenças sexualmente transmissíveis em idosos: uma revisão sistemática. Ciênc Saúde Colet. 2015;20(12):3853-64. Disponível em: http:// www.scielo.br/scielo.php?script=sci_arttext\&pid $=$ S1413-81232015001203853

13. Santos AFM, de Assis M. Vulnerabilidade das idosas ao HIV/AIDS: despertar das políticas públicas e profissionais de saúde no contexto da atenção integral: revisão de literatura. Rev Bras Geriatr Gerontol. 2011;14(1):147-57.

14. Celedônio RM, Jorge MSB, Santos DCM, Freitas CHA, Aquino FOTP. Políticas de educação permanente e formação em saúde: uma análise documental. Rev Rene [Internet]. 2012 [acesso em 8 maio 2016];13(5):1000-10.

15. Araújo VLB, Brito DMS, Gimeniz MT, Queiroz TA, Tavares CM. Características da AIDS na terceira idade em um hospital de referência do Estado do Ceará. Rev Bras Epidemiol [Internet]. 2007 [acesso em 02 mar 2016];10(4):544-54. Disponível em: http://www. scielo.br/scielo.php?script $=$ sci_arttext\&pid=S1415790X2007000400013\&lng=en

16. Pedrosa NL, Paiva SS, de Almeida RL, de Holanda ER, Kerr LR, Galvão MT. The historic data series on AIDS in the state of Ceará, Brazil. Ciênc Saúde Colet. 2015;20(4):1177-84.
17. Brasil. Secretaria de Vigilância em Saúde, Ministério Da Saúde. Bol Epidemiol HIV/ AIDS. Brasília, DF. Vol. 5, No. 1, 01 dez. 2017.

18. Ceará. Secretaria da Saúde. Boletim epidemiológico HIV/AIDS 2015 [Internet]. Ceará: Secretaria da saúde; 2016 [acesso em 18 set. 2017]. Disponível em: http://www.saude.ce.gov.br

19. Tomazelli J, Czeresnia D, Barcellos C. Distribuição dos casos de AIDS em mulheres no Rio de Janeiro, de 1982 a 1997: uma análise espacial. Cad Saúde Pública [Internet]. 2003 [acesso em 14 mar. 2016];19(4):1049-61. Disponível em: http://www.scielo.br/scielo.php?script $=$ sci arttext\&pid=S0102-311X2003000400027\&lng=en

20. Allfredt AB, Silveira MF, Barcelos RS. Perfil de pessoas idosas vivendo com HIV/AIDS em Pelotas, sul do Brasil, 1998 a 2013. Epidemiol Serv Saúde. 2015;24(1):79-86.

21. Laroque MF, Affeldt AB, Cardoso DH, Souza GL, Santana MG, Lange C. Sexualidade do idoso: comportamento para a prevenção de DST/AIDS. Rev Gaúcha Enferm [Internet]. 2011 [acesso em 19 abr. 2017];32(4):774-80. Disponível em: http://www. scielo.br/scielo.php?script $=$ sci_arttext\&pid=S1983$14472011000400019 \& \operatorname{lng}=\mathrm{pt} \& \ln \mathrm{l}=\mathrm{pt}$

22. Gomes RRFM, Ceccato MGB, Kerr LRFS, Guimarães MDC. Fatores associados ao baixo conhecimento sobre HIV/AIDS entre homens que fazem sexo com homens no Brasil. Cad Saúde Pública [Internet]. 2017 [acesso em 20 jun. 2018];33(10): 1-13. Disponível em: http://www.scielo.br/scielo. php?script=sci_arttext\&pid=S0102-311X2017001005 $001 \& \operatorname{lng}=$ pt\&nrm $=$ iso\&tlng $=$ pt

23. Andrade HAS, Silva SK, Santos MPIO. AIDS em idosos: vivências dos doentes. Esc Anna Nery [Internet]. 2010 [acesso em 14 Dez 2017];14(4):712-9. Disponível em: http://www. scielo.br/scielo.php?script $=$ sci_arttext\&pid $=$ S141481452010000400009\&lng=en

24. Gurgel SN, Lubenow JAM, Moreira MASP, Ferreira OGL, de Pinho TAM, Nogueira JA. Vulnerabilidade do idoso ao HIV: revisão integrativa. Rev Enferm UFPE on line. 2014;8 (Supl. 1):2487-93.

25. Agência IBGE Notícias [Internet]. Sem Local: IBGE; 2016- . PNAD continua 2016: 51\% da população com 25 anos ou mais no Brasil... 2016 [acesso em 14 dez. 2017]; [1 tela]. Disponível em: https://agenciadenoticias.ibge.gov.br/ agencia-noticias/2013-agencia-de-noticias/ releases/18992-pnad-continua-2016-51-da-populacaocom-25-anos-ou-mais-do-brasil-possuiam-apenas-oensino-fundamental-completo.html

26. Hekmatpou D, Shamsi M, Zamani M. The effect of a healthy lifestyle program on the elderly's health in Arak. Indian J Med Sci. 2013;67(3-4):70-7. 
27. Oliveira JL. A vida cotidiana do idoso morador de rua: as estratégias de sobrevivência da infância à velhice: um círculo da pobreza a ser rompido [dissertação]. Porto Alegre: Pontifícia Universidade Católica do Rio Grande do Sul, Faculdade de Serviço Social; 2012.

28. Okuno MFP, Gomes AC, Meazzini L, Scherrer Junior G, Belasco Junior D, Belasco AGS. Qualidade de vida de pacientes idosos vivendo com HIV/AIDS. Cad Saúde Pública. 2014;30(7):1551-9.

Received: March 14, 2018

Reviewed: July 26, 2018

Accepted: August 01, 2018
29. Moreira WC, Lago EC, Viana MRP, Carvalho ARB, Frota BC, Pereira PSL. Sexualidade e prevenção de IST e HIV/aids entre idosos usuários da estratégia saúde da família. Rev Prev Infecç Saúde. 2015;1(3):76-82.

30. Brasil. Ministério da Saúde. Portaria no. 2104, de 19 de novembro de 2002. Institui, no âmbito do Sistema Único de Saúde - SUS, o Projeto NascerMaternidades. Saúde Legis; 2002. Disponível em: http://bvsms.saude.gov.br/bvs/saudelegis/gm/2002/ prt2104_19_11_2002.html 